\title{
LABORATORY EFFECT OF Boni Protect CONTAINING Aureobasidium pullulans (de Bary) Arnoud IN THE CONTROL OF SOME FUNGAL DISEASES OF APPLE FRUIT
}

\author{
Anna Wagner', Beata Hetman', Marek Kopacki', Agnieszka Jamiołkowska1, \\ Pawel Krawiec ${ }^{2}$, Tomasz Lipa ${ }^{2}$ \\ ${ }^{1}$ Department of Plant Protection and Quarantine, University of Life Sciences Leszczynskiego 7, 20-069 Lublin, Poland \\ ${ }^{2}$ Department of Pomology, University of Life Sciences Leszczynskiego 58, 20-069 Lublin, Poland \\ e-mail:wagnerania@gmail.com
}

Received: 30.06 .2012

\section{Abstract}

The efficacy of Aureobasidium pullulans (in the biopreparation Boni Protect) against different pathogens of apples (Botrytis cinerea, Monilinia fructigena, Penicillium expansum, and Pezicula malicorticis) was evaluated under laboratory conditions. The biocontrol product was applied at concentrations of $0.05 \%, 0.1 \%$, and $0.5 \%$. Fruits of apple cultivars 'Jonagold Decosta' and 'Pinova' were used. Boni Protect was very effective against $B$. cinerea on cv. 'Jonagold Decosta', reducing disease incidence by $55-83.8 \%$. On 'Pinova' apples, this biological control product was the most efficient at earlier stages of the experiment. It inhibited grey mold by $65 \%$ after 5 days from inoculation and only by $14 \%$ after 20 days. On cv. 'Jonagold Decosta', Boni Protect at a concentration of $0.1 \%$ was also effective against $M$. fructigena, reducing brown rot by 31.4-74.5\%, but its efficiency on cv. 'Pinova' was not significant. Blue mold caused by $P$. expansum was inhibited only slightly by the biocontrol product, while $P$. malicorticis proved to be the most resistant to its antagonistic abilities.

Key words: apple fruit, Aureobasidium pullulans, biocontrol, Botrytis cinerea, Monilinia fructigena, Penicillium expansum, Pezicula malicorticis

\section{INTRODUCTION}

Fungal diseases cause major losses in apple production. The most important pathogens of apple fruits are Pezicula alba Gunthrie, Pezicula malicorticis (Jacks.) Nannf., Botrytis cinerea Pers., Monilinia fructigena (Aderh. et Ruhl.) Honey, and Penicillium expansum Link. The importance of each pathogen depends on climatic and storage conditions as well as on the growing system. The protection of apples is dif- ficult because many fungi are resistant to fungicides (Rosslenbroich and Stuebler, 2000) and customers are afraid of chemical residues in fruits. Recently, more attention has been paid to microorganisms occurring on fruits under natural conditions and to their abilities to protect fruits against pathogens (V in a s et al. 1998; W a g n e r et al. 2006). One of these microorganisms is a yeast-like fungus Aureobasidium pullulans (De Bary) Arnoud. The fungus is a widespread epiphyte well adapted to the phyllosphere and carposphere. Some A. pullulans isolates exhibit antagonistic activity against a number of phytopathogenic fungi (S chen a et al. 1999, 2003), competing for nutrients and space and producing numerous compounds such as pectolytic enzymes (Pouli ot et al. 2005), antimicrobial metabolites ( T a kes a k o et al. 1991), and high-molecular-weight polysaccharides (pullulan) (Pras ong su k et al. 2005). The fungus colonizes the surface of fruits and induces their resistance to fungal pathogens, especially those involved in postharvest diseases. Therefore, it can be used as a biocontrol agent against pathogens (e.g. Botrytis cinerea and Penicillium expansum) ( $\mathrm{S} \mathrm{ch}$ e $\mathrm{n}$ a et al. 1999; P ouli o t et al. 2005). Based on this fungus, the biopreparation Boni Protect was developed and it is now produced by Bio-Protect $\mathrm{GmbH}$. The active ingredients are two strains of $A$. pullulans isolated from apples at LS Phytopathology of Konstanz University. This biocontrol product contains living blastospores of A. pullulans in natural medium.

The aim of the study was to estimate the effect of A. pullulans in Boni Protect on the development of some fungal diseases of apple fruit. 


\section{MATERIALS AND METHODS}

Aureobasidium pullulans was used in the biocontrol product Boni Protect (produced by Bio-Protect Gmbh, Konstanz, Germany). This biopreparation was tested at concentrations of $0.05 \%, 0.1 \%$, and $0.5 \%$. Four species of fungi (Botrytis cinerea, Monilinia fructigena, Penicillium expansum, Pezicula malicorticis) isolated from apples were used in the experiment. The study was carried out on fruits of cvs 'Jonagold Decosta' and 'Pinova'. The surface of fruits was sterilized with $70 \%$ ethanol. With a sterilized cork borer, four $2 \mathrm{~mm}$ deep holes were made in each fruit at the same distance from each other. $5 \mu \mathrm{l}$ of Boni Protect suspension at each concentration was introduced into each hole. In the control combinations, $5 \mathrm{ml}$ of sterilized water was used. After $24 \mathrm{hrs} 3 \mathrm{~mm}$ disks of mycelium of each pathogen were placed in the holes. Before that, the fungi were grown for 10 days on PDA medium (Difco) in Petri dishes. 6 fruits were tested for Boni Protect in one of the concentrations, one of the pathogens, and one of the cultivars. The apples were placed in plastic containers disinfected with ethanol and stored in a chamber at $22^{\circ} \mathrm{C}$ and relative humidity of $80 \%$. The diameters of necrotic spots were measured after 5, 10, 15 and 20 days of incubation.

The fungistatic activity of the biocontrol product was estimated as the percentage of inhibition of rot development on apples compared to the control according to Abbott's formula (B o r e c k i , 1984):

$$
\begin{aligned}
& \mathrm{C}-\mathrm{T} \\
& \mathrm{I}(\%)=\times 100 \% \\
& \mathrm{C} \\
& \text { where: } \\
& \mathrm{I}-\text { inhibition index }(\%) \text {; } \\
& \mathrm{C} \text { - necrosis diameter in the control treatment; } \\
& \quad \text { - necrosis diameter in the treatment conta- } \\
& \quad \text { ining the biopreparation. }
\end{aligned}
$$

The data were analyzed by analysis of variance (Duncan's test) at a significance level of 5\% using the SAS statistical system, ANOVA (SAS Version 9.1, SAS Inst., Cary, N.C., U.S.A.).

\section{RESULTS}

The results showed that the efficacy of $A u$ reobasidium pullulans in Boni Protect depends on pathogen species, product concentration, and apple cultivar. The biopreparation was the most effective in controlling fruit rot caused by $B$. cinerea and M. fructigena. Aureobasidium pullulans strongly inhibited the development of diseases already after 5 days of experiment. The size of necrotic spots caused by B. cinerea on 'Jonagold Decosta' fruits was significantly smaller in the treatments with Boni Protect than in the control combination. The biopreparation was effective at all concentrations but the strongest effect was achieved at the concentration of $0.5 \%$ after 10 days (83.8\%). Aureobasidium pullulans was less effective on apples of 'Pinova', although in most combinations the development of disease was significantly slower than in the control combination. The best results were achieved after 5 days of experiment but after 20 days the necrotic spots were significantly smaller only when $0.1 \%$ concentration of the product was used (Tables 1-2, Figs 1-2, 9).

Brown rot caused by $M$. fructigena can also be controlled by A. pullulans. The biocontrol product in $0.1 \%$ concentration proved to be very efficient on $\mathrm{cv}$. 'Jonagold Decosta' fruits, inhibiting the development of disease by $31.4-78.4 \%$. The strongest effect was noticed after 15 days after the inoculation. The other concentrations were not effective. The concentration of $0.1 \%$ was the most efficient also on cv. 'Pinova' apples but the diameters of spots did not differ significantly from the control combination (Tables 1-2, Figs 3-4, 10).

The efficacy of A. pullulans to control rots caused by $P$. expansum and $P$. malicorticis was much lower. On 'Jonagold Decosta' apples, the concentration of $0.1 \%$ inhibited significantly $P$. expansum rot after 5,15 and 20 days, the concentration of $0.5 \%$ after 10,15 and 20 days, whereas the concentration of $0.05 \%$ only after 5 days. The differences between the treatments and controls were much smaller than in the combinations with $B$. cinerea and $M$. fructigena. On cv. 'Pinova' fruits, only the development of Penicillium rot was slightly inhibited and only at the beginning of the experiment. The rot caused by P. malicorticis was not inhibited by Boni Protect (Tables 1-2, Figs 5-8, 11-12). 
Table 1

Effect of Boni Protect on necrosis diameter on 'Pinova' apples

\begin{tabular}{|c|c|c|c|c|c|}
\hline \multirow{2}{*}{ Fungus species } & \multirow{2}{*}{ Experimental combination } & \multicolumn{4}{|c|}{ Mean diameter of necrosis (mm) } \\
\hline & & 5 days & 10 days & 15 days & 20 days \\
\hline \multirow{4}{*}{ Botrytis cinerea } & Control & $22.9 a^{*}$ & $45.23 \mathrm{a}^{*}$ & $53.65 a^{*}$ & $50.33 \mathrm{ab} *$ \\
\hline & B1 & $8.67 \mathrm{~b}$ & $27.70 \mathrm{~b}$ & $46.35 \mathrm{ab}$ & $51.96 \mathrm{a}$ \\
\hline & B2 & $9.30 \mathrm{~b}$ & $23.69 b$ & $36.73 \mathrm{c}$ & $43.60 \mathrm{~b}$ \\
\hline & B3 & $6.85 b$ & $23.65 b$ & $41.10 \mathrm{bc}$ & $51.90 \mathrm{a}$ \\
\hline \multicolumn{2}{|c|}{ LSD (0.05) } & 3.90 & 9.45 & 8.57 & 7.06 \\
\hline \multirow{4}{*}{ Monilinia fructigena } & Control & $8.67 \mathrm{a}^{*}$ & $20.73 a^{*}$ & $47.27 \mathrm{a}^{*}$ & $52.85 \mathrm{a}^{*}$ \\
\hline & B1 & $8.02 \mathrm{a}$ & $26.56 a$ & $43.42 \mathrm{a}$ & $44.33 \mathrm{a}$ \\
\hline & B2 & $7.42 \mathrm{a}$ & $18.10 \mathrm{a}$ & $39.81 \mathrm{a}$ & $47.92 \mathrm{a}$ \\
\hline & B3 & $9.04 \mathrm{a}$ & $19.78 \mathrm{a}$ & $40.56 \mathrm{a}$ & $46.33 \mathrm{a}$ \\
\hline \multicolumn{2}{|c|}{ LSD (0.05) } & 4.47 & 12.83 & 11.88 & 11.50 \\
\hline \multirow{4}{*}{ Penicillium expansum } & Control & $23.35 \mathrm{a}^{*}$ & $35.69 a^{*}$ & $40.27 a^{*}$ & $39.06 a^{*}$ \\
\hline & B1 & $19.44 b$ & $33.35 b$ & $38.63 \mathrm{a}$ & $37.48 \mathrm{a}$ \\
\hline & B2 & $20.90 b$ & $35.52 \mathrm{a}$ & $39.69 a$ & $37.44 \mathrm{a}$ \\
\hline & B3 & $20.02 b$ & $34.60 \mathrm{ab}$ & $40.19 \mathrm{a}$ & $39.04 \mathrm{a}$ \\
\hline \multicolumn{2}{|c|}{$\operatorname{LSD}(0.05)$} & 2.25 & 1.80 & 2.16 & 2.14 \\
\hline \multirow{4}{*}{ Pezicula malicorticis } & Control & $4.96 a^{*}$ & $4.96 a^{*}$ & $5.96 a^{*}$ & $6.42 c^{*}$ \\
\hline & B1 & $4.96 \mathrm{a}$ & $5.17 \mathrm{a}$ & $5.88 \mathrm{a}$ & $8.38 \mathrm{a}$ \\
\hline & B2 & $5.00 \mathrm{a}$ & $5.31 \mathrm{a}$ & $6.04 \mathrm{a}$ & 7.79ab \\
\hline & B3 & $4.83 \mathrm{a}$ & $5.13 \mathrm{a}$ & $5.79 \mathrm{a}$ & $7.50 \mathrm{~b}$ \\
\hline \multicolumn{2}{|c|}{ LSD (0.05) } & 0.51 & 0.47 & 0.47 & 0.68 \\
\hline
\end{tabular}

B1 - $0.05 \%$ concentration of Boni Protect; B2 - 0.1\% concentration of Boni Protect; B $-0.5 \%$ concentration of Boni Protect *values designated with the same letters $(\mathrm{a}, \mathrm{b}, \mathrm{c} \ldots)$ within columns do not significantly differ at $5 \%$ error (Duncan's test)

Table 2

Effect of Boni Protect on necrosis diameter on 'Jonagold Decosta' apples

\begin{tabular}{|c|c|c|c|c|c|}
\hline \multirow{2}{*}{ Fungus species } & \multirow{2}{*}{ Experimental combination } & \multicolumn{4}{|c|}{ Mean diameter of necrosis (mm) } \\
\hline & & 5 days & 10 days & 15 days & 20 days \\
\hline \multirow{4}{*}{ Botrytis cinerea } & Control & $15.48 \mathrm{a}^{*}$ & $37.50 a^{*}$ & $47.15 \mathrm{a}^{*}$ & $51.52 \mathrm{a}^{*}$ \\
\hline & B1 & $5.83 b$ & $7.58 \mathrm{~b}$ & $13.33 b$ & $23.69 b$ \\
\hline & B2 & $5.48 b$ & $8.75 b$ & $14.27 \mathrm{~b}$ & $23.92 b$ \\
\hline & B3 & $5.17 \mathrm{~b}$ & $6.06 \mathrm{~b}$ & $12.00 \mathrm{~b}$ & $20.48 b$ \\
\hline \multicolumn{2}{|c|}{ LSD (0.05) } & 3.19 & 7.43 & 10.51 & 15.04 \\
\hline \multirow{4}{*}{ Monilinia fructigena } & Control & $8.08 \mathrm{a}^{*}$ & $15.10 \mathrm{bc} *$ & $26.58 b *$ & $35.58 \mathrm{~b} *$ \\
\hline & B1 & $6.65 \mathrm{a}$ & $16.29 b$ & $42.44 \mathrm{a}$ & $48.83 a$ \\
\hline & B2 & $5.54 \mathrm{a}$ & $5.58 \mathrm{c}$ & $5.75 \mathrm{c}$ & $17.27 \mathrm{c}$ \\
\hline & B3 & $8.90 \mathrm{a}$ & $29.79 \mathrm{a}$ & $52.44 \mathrm{a}$ & $55.92 \mathrm{a}$ \\
\hline \multicolumn{2}{|c|}{$\operatorname{LSD}(0.05)$} & 4.55 & 10.41 & 11.56 & 12.24 \\
\hline \multirow{4}{*}{ Penicillium expansum } & Control & $26.06 \mathrm{a}^{*}$ & $36.92 \mathrm{a}^{*}$ & $44.67 \mathrm{ab}^{*}$ & $46.08 \mathrm{a}^{*}$ \\
\hline & B1 & $23.50 \mathrm{~b}$ & $38.94 a$ & $46.17 \mathrm{a}$ & $46.40 \mathrm{a}$ \\
\hline & B2 & $22.10 \mathrm{~b}$ & $36.79 \mathrm{a}$ & $42.85 b c$ & $40.71 \mathrm{~b}$ \\
\hline & B3 & $18.15 \mathrm{c}$ & $34.10 \mathrm{~b}$ & $41.46 \mathrm{c}$ & $41.63 b$ \\
\hline \multicolumn{2}{|c|}{ LSD (0.05) } & 2.45 & 2.39 & 2.28 & 2.25 \\
\hline \multirow{4}{*}{ Pezicula malicorticis } & Control & $5.00 \mathrm{a}^{*}$ & $5.08 \mathrm{a}^{*}$ & $5.75 a^{*}$ & $7.17 \mathrm{a}^{*}$ \\
\hline & B1 & $4.92 \mathrm{a}$ & $5.17 \mathrm{a}$ & $5.83 \mathrm{a}$ & $6.38 \mathrm{~b}$ \\
\hline & B2 & $4.96 a$ & $5.13 \mathrm{a}$ & $5.79 a$ & $6.21 b$ \\
\hline & B3 & $5.08 \mathrm{a}$ & $5.08 \mathrm{a}$ & $5.29 \mathrm{~b}$ & $6.42 b$ \\
\hline \multicolumn{2}{|c|}{$\operatorname{LSD}(0.05)$} & 0.44 & 0.43 & 0.40 & 0.40 \\
\hline
\end{tabular}

B1 - $0.05 \%$ concentration of Boni Protect; B2 - $0.1 \%$ concentration of Boni Protect; B $-0.5 \%$ concentration of Boni Protect *values designated with the same letters $(\mathrm{a}, \mathrm{b}, \mathrm{c} . .$.$) within columns do not significantly differ at 5 \%$ error (Duncan's test) 


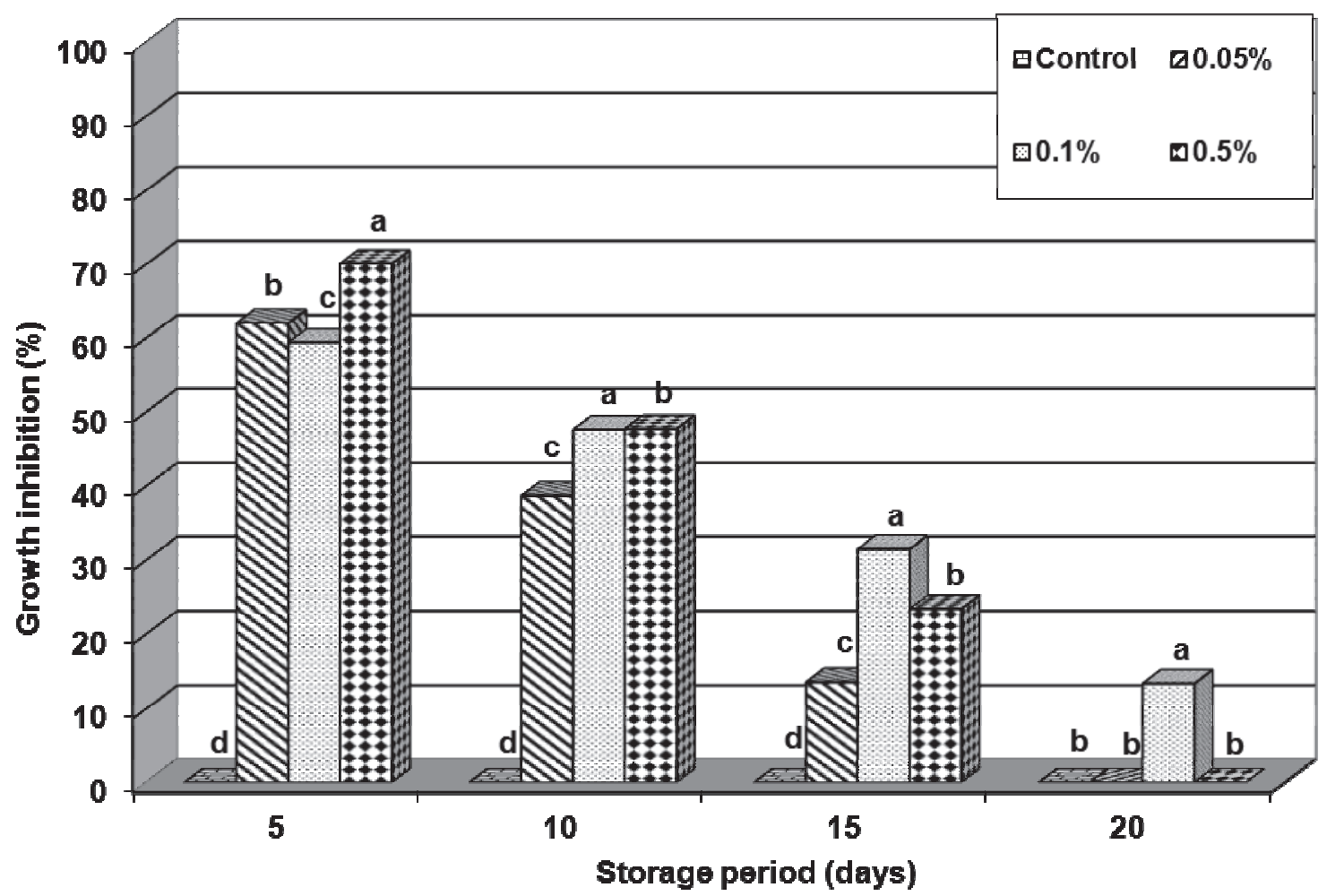

Columns designated with the same letter $(\mathrm{a}, \mathrm{b}, \mathrm{c} \ldots)$ do not differ significantly at $5 \%$ error (Duncan's test) within the duration of the experiment

Fig. 1. Effect of Boni Protect on the inhibition of necrosis caused by B. cinerea on 'Pinova'.

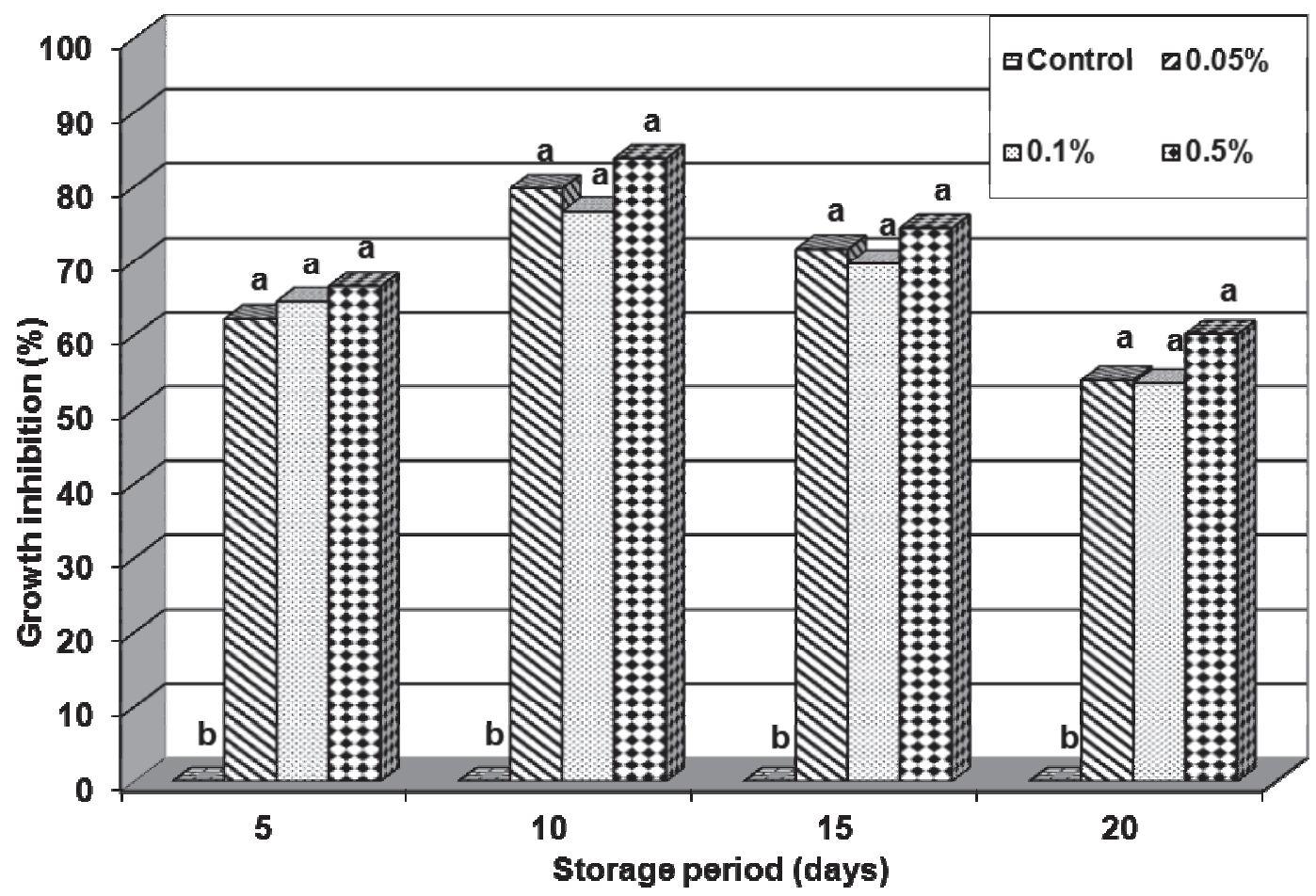

Columns designated with the same letter $(\mathrm{a}, \mathrm{b}, \mathrm{c} . .$.$) do not differ significantly at 5 \%$ error (Duncan's test) within the duration of the experiment

Fig. 2. Effect of Boni Protect on the inhibition of necrosis caused by B. cinerea on 'Jonagold Decosta'. 


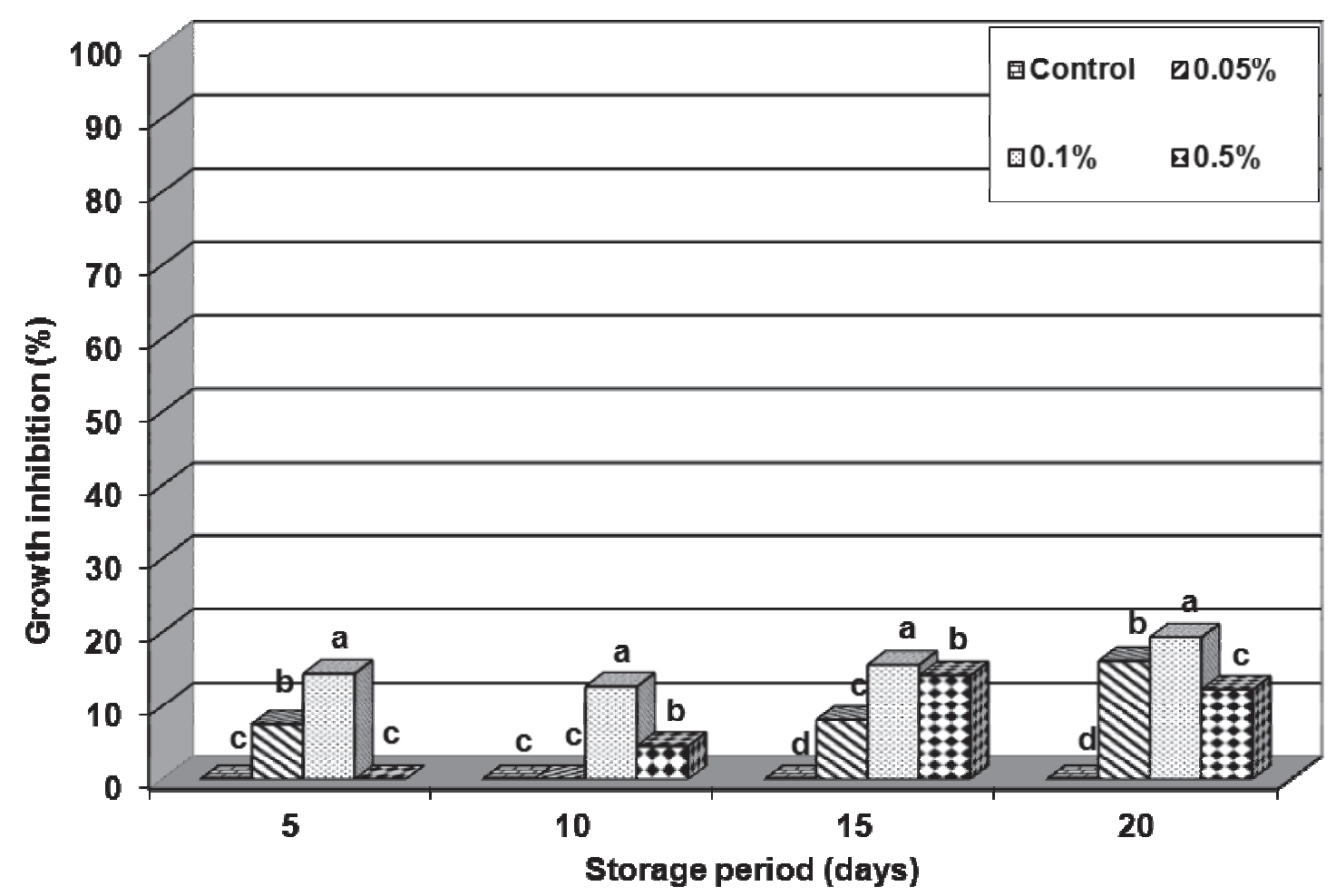

Columns designated with the same letter $(a, b, c .$.$) do not differ significantly at 5 \%$ error (Duncan's test) within the duration of the experiment

Fig. 3. Effect of Boni Protect on the inhibition of necrosis caused by M. fructigena on 'Pinova'.

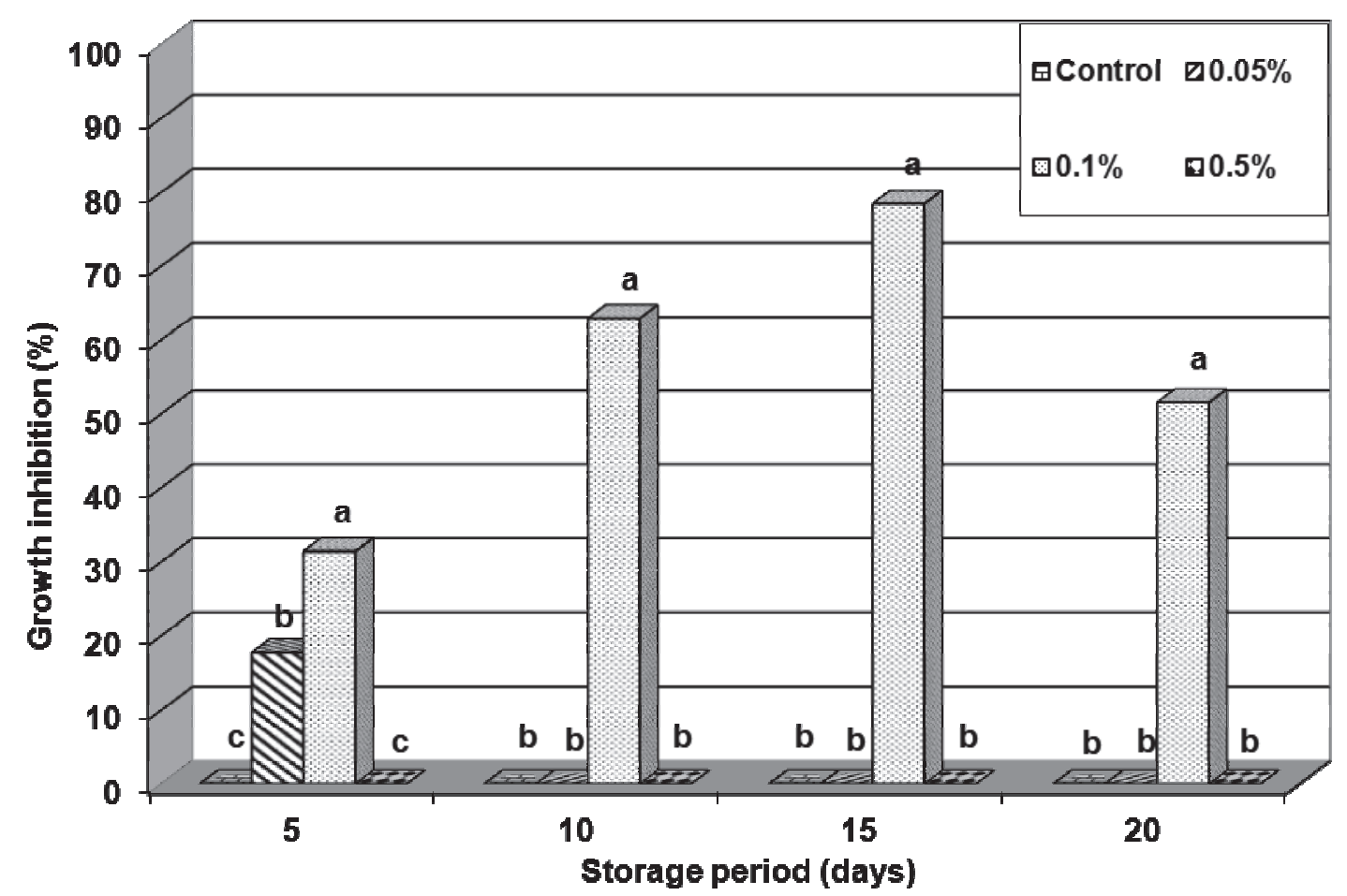

Columns designated with the same letter $(a, b, c \ldots)$ do not differ significantly at 5\% error (Duncan's test) within the duration of the experiment

Fig. 4. Effect of Boni Protect on the inhibition of necrosis caused by M. fructigena on 'Jonagold Decosta'. 


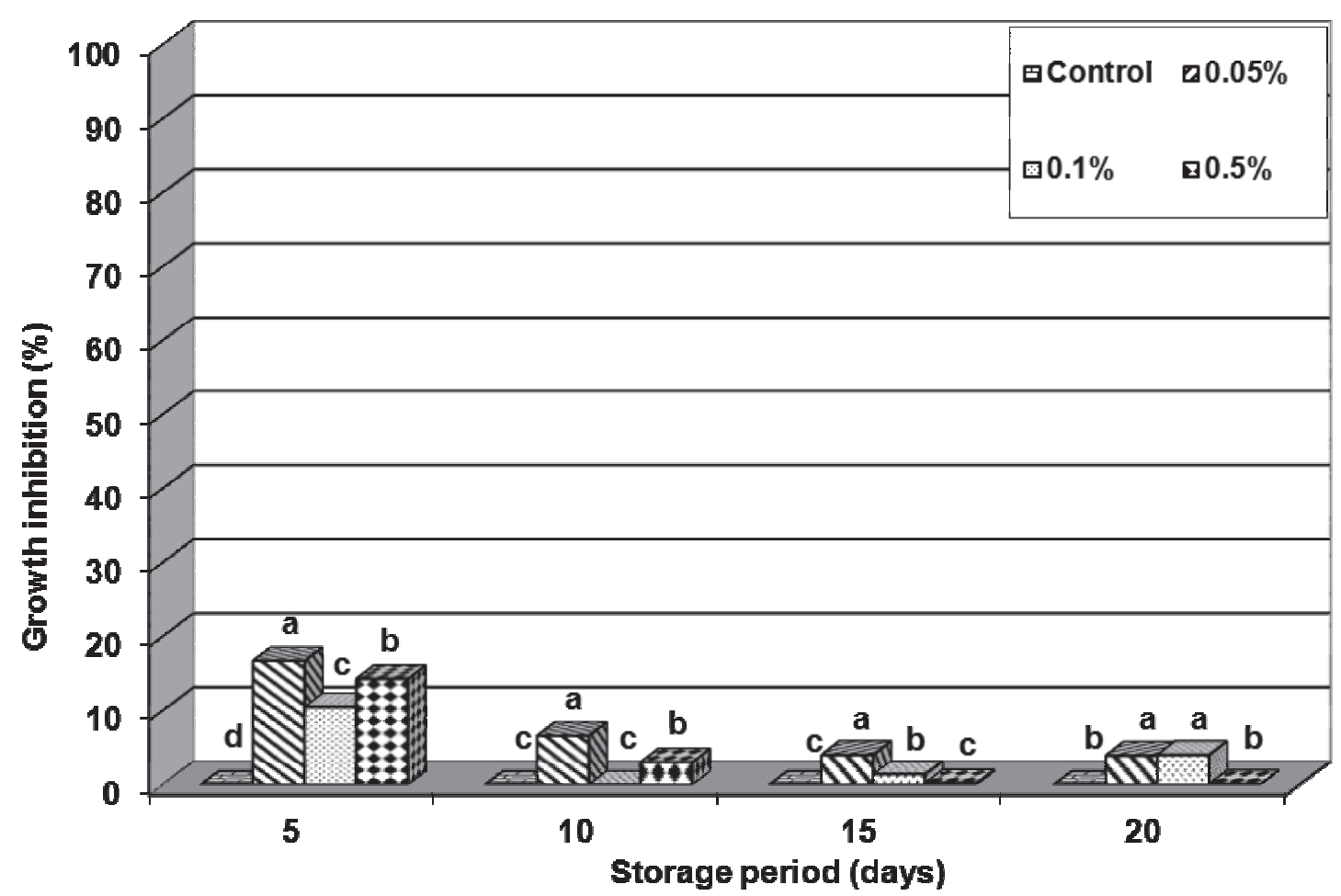

Columns designated with the same letter $(a, b, c \ldots)$ do not differ significantly at $5 \%$ error (Duncan's test) within the duration of the experiment

Fig. 5. Effect of Boni Protect on the inhibition of necrosis caused by P. expansum on 'Pinova'.

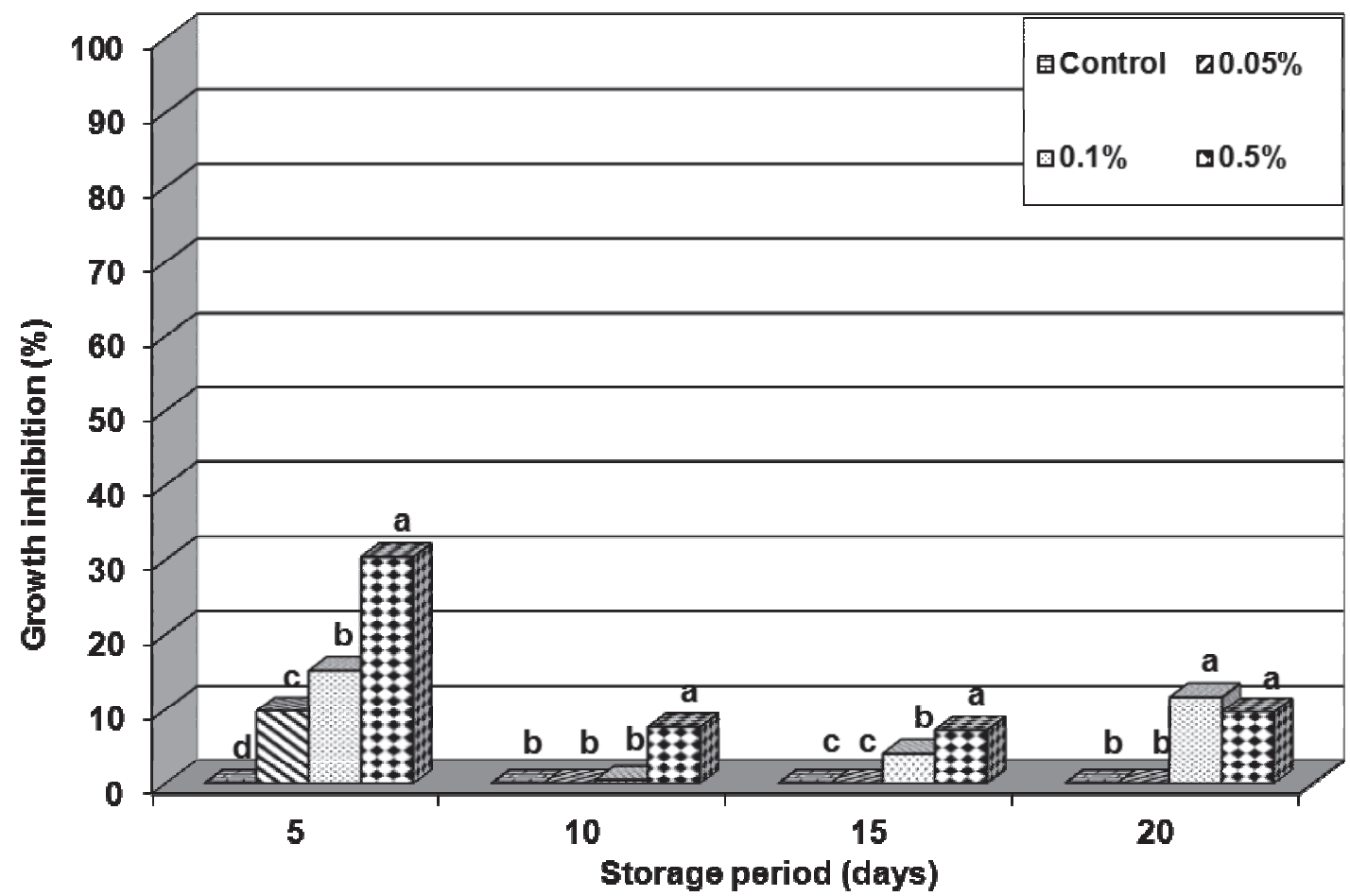

Columns designated with the same letter $(\mathrm{a}, \mathrm{b}, \mathrm{c} . .$.$) do not differ significantly at 5 \%$ error (Duncan's test) within the duration of the experiment

Fig. 6. Effect of Boni Protect on the inhibition of necrosis caused by P. expansum on 'Jonagold Decosta'. 


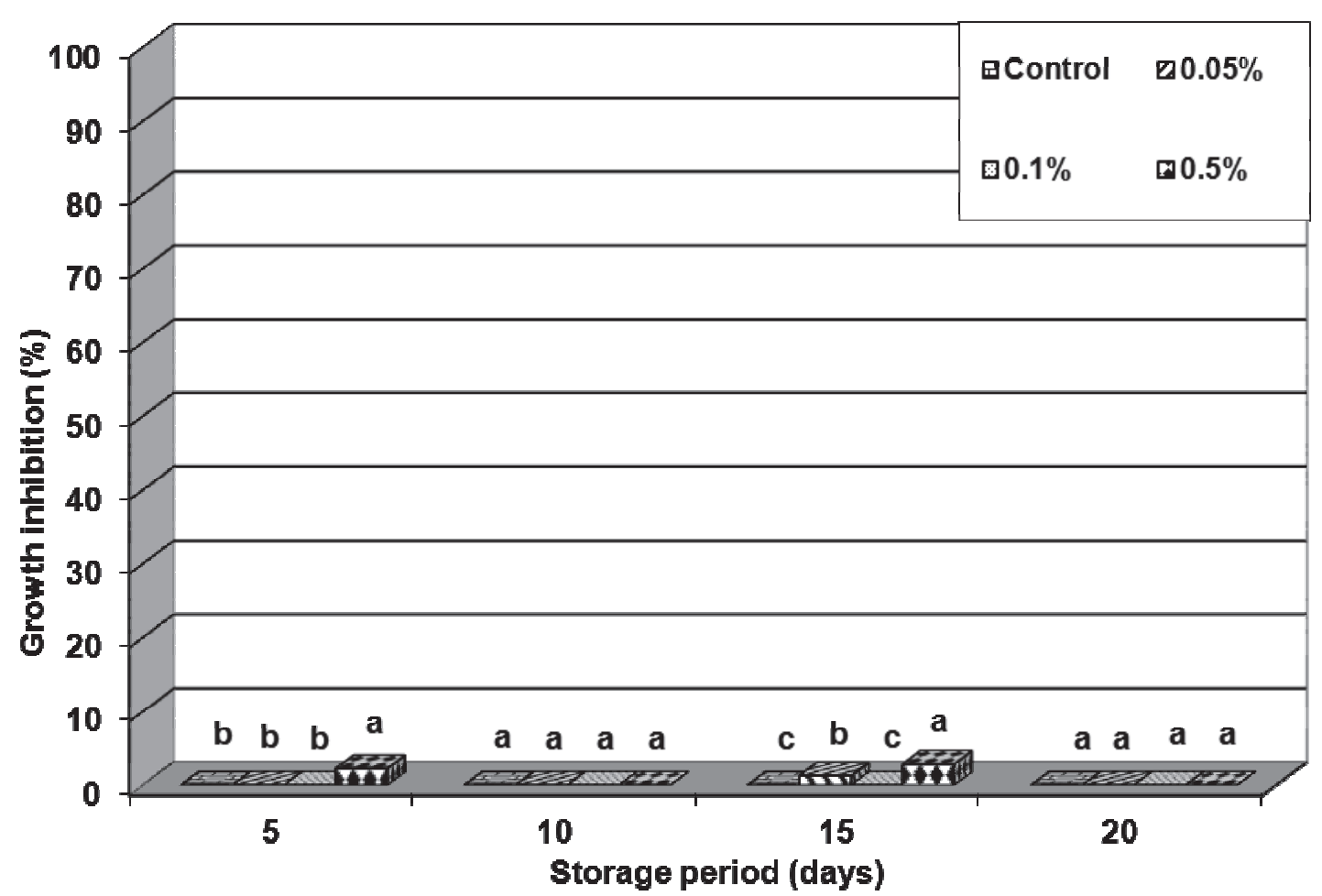

Columns designated with the same letter $(a, b, c \ldots)$ do not differ significantly at $5 \%$ error (Duncan's test) within the duration of the experiment

Fig. 7. Effect of Boni Protect on the inhibition of necrosis caused by P. malicorticis on 'Pinova'.

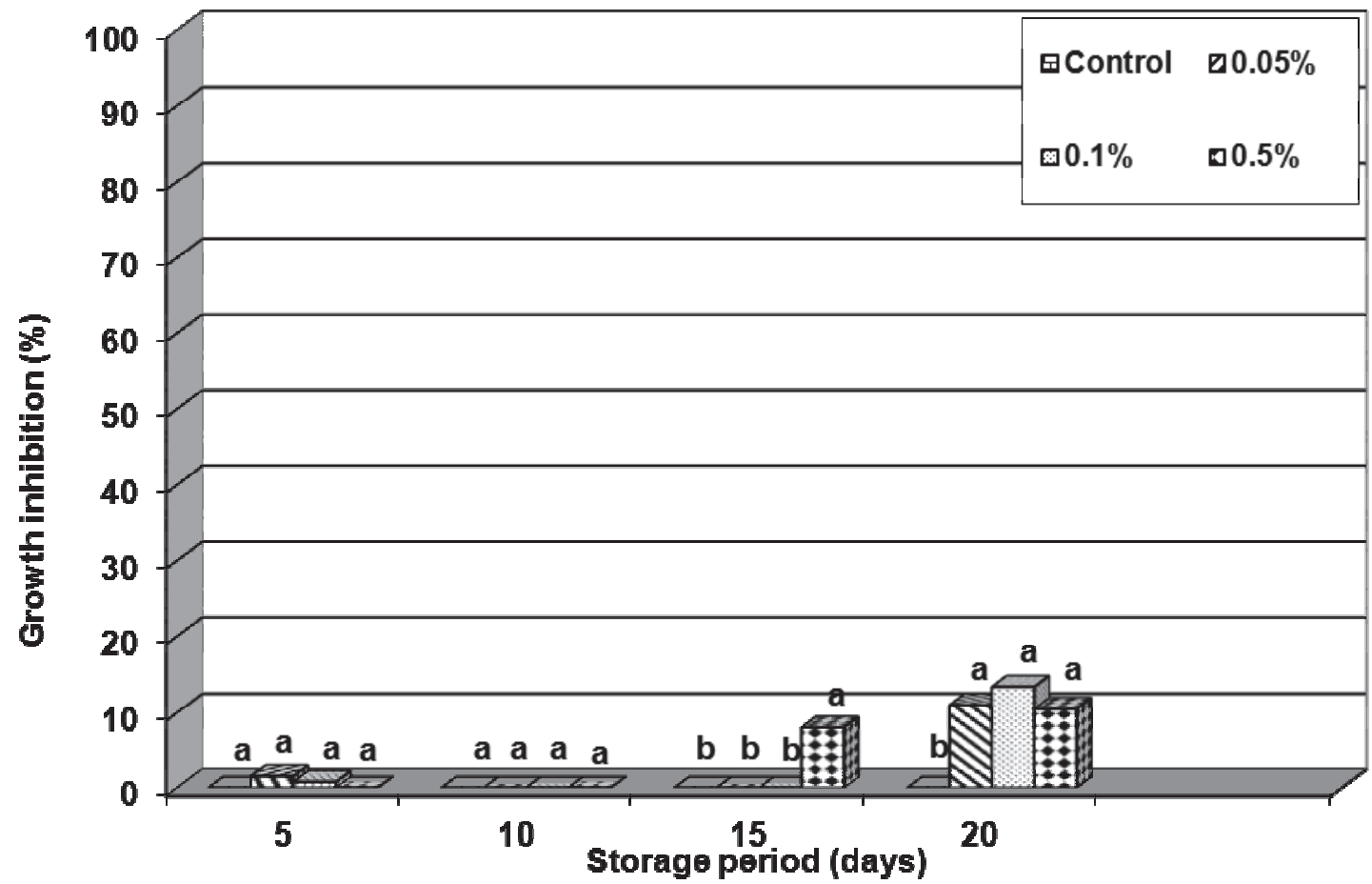

Columns designated with the same letter $(a, b, c \ldots)$ do not differ significantly at 5\% error (Duncan's test) within the duration of the experiment

Fig. 8. Effect of Boni Protect on the inhibition of necrosis caused by P. malicorticis on 'Jonagold Decosta'. 


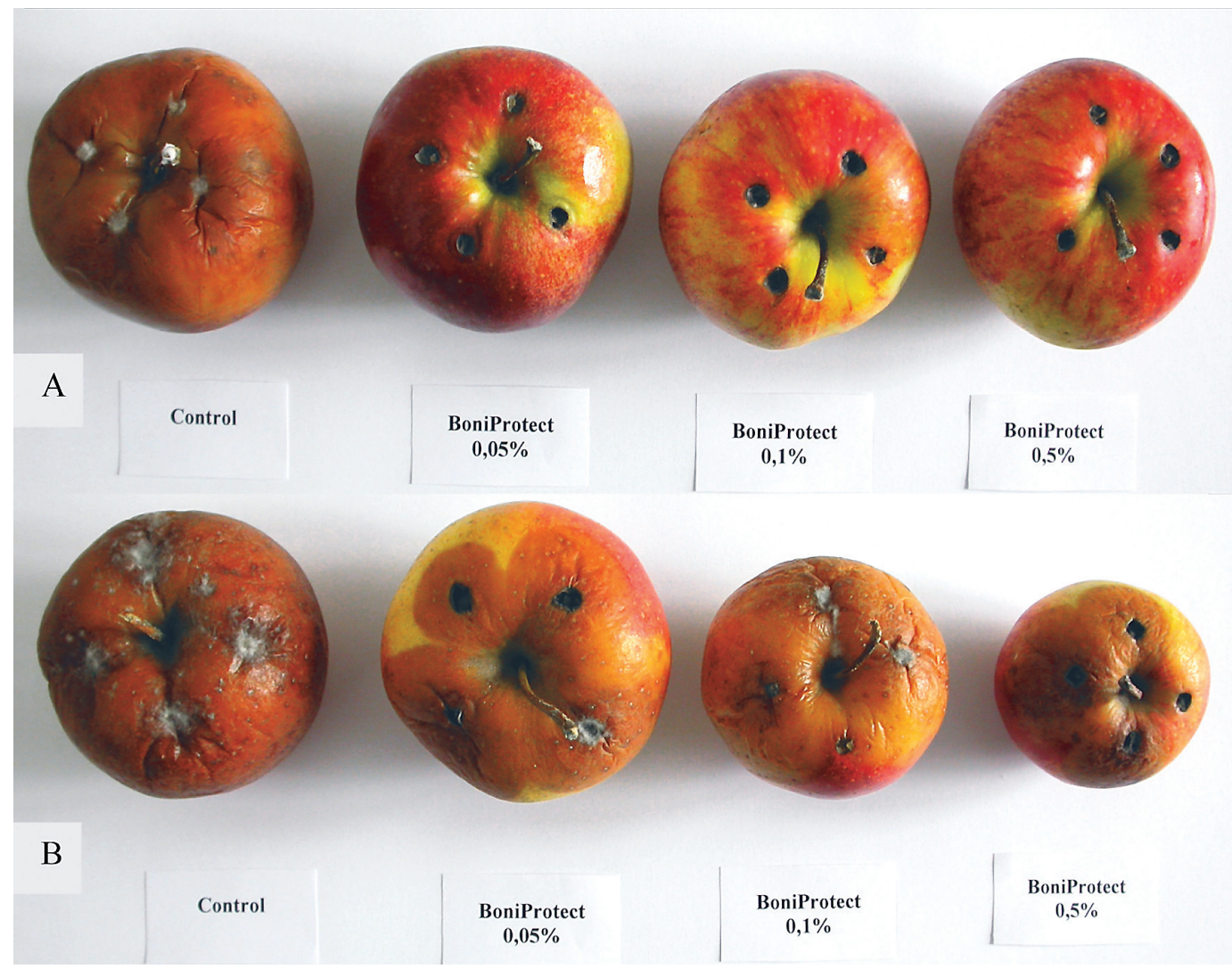

Fig. 9. Effect of Boni Protect on grey mold (Penicillum expansum) development on 'Jonagold Decosta' (A) and 'Pinova' (B) after 10 days.

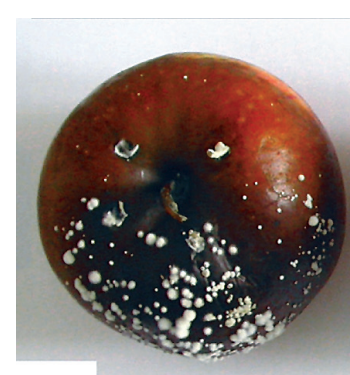

A

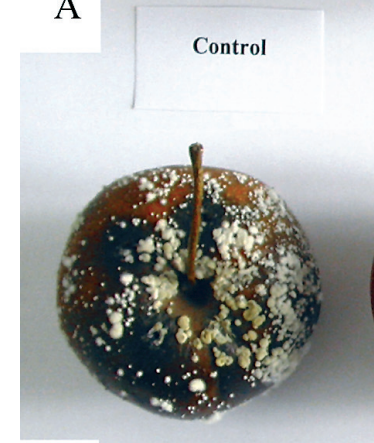

B

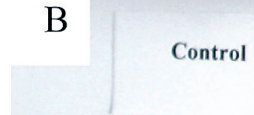

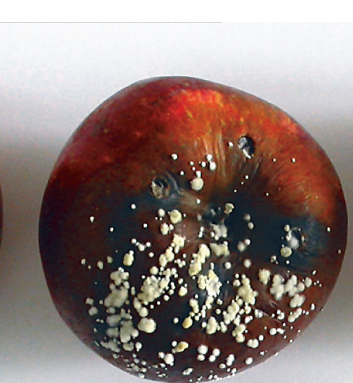

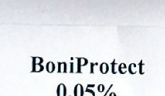

$0,05 \%$

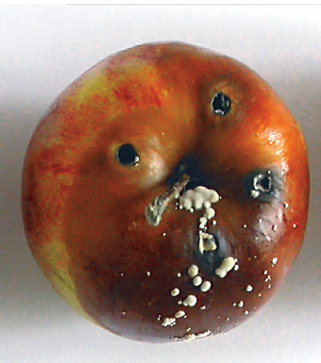

BoniProtect
$0,1 \%$

$0,1 \%$

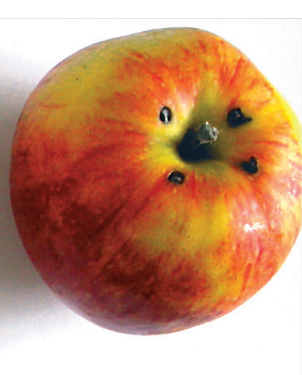

BoniProtect
$0,5 \%$

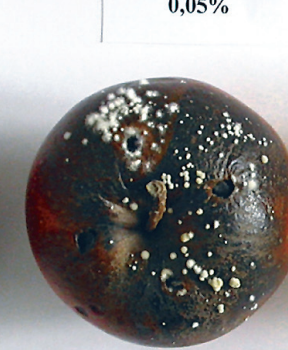

BoniProtect

$0,05 \%$

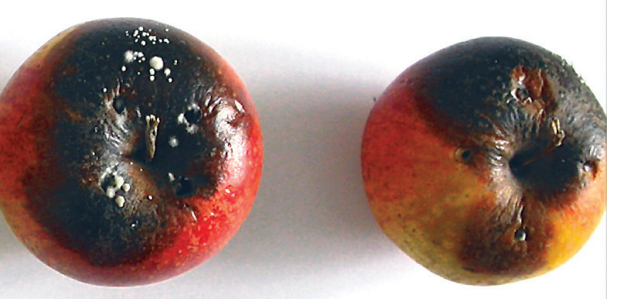

BoniProtect $0,1 \%$
BoniProtec

Fig. 10. Effect of Boni Protect on brown rot (Monilinia fructigena) development on 'Jonagold Decosta' (A) and 'Pinova' (B) after 10 days. 


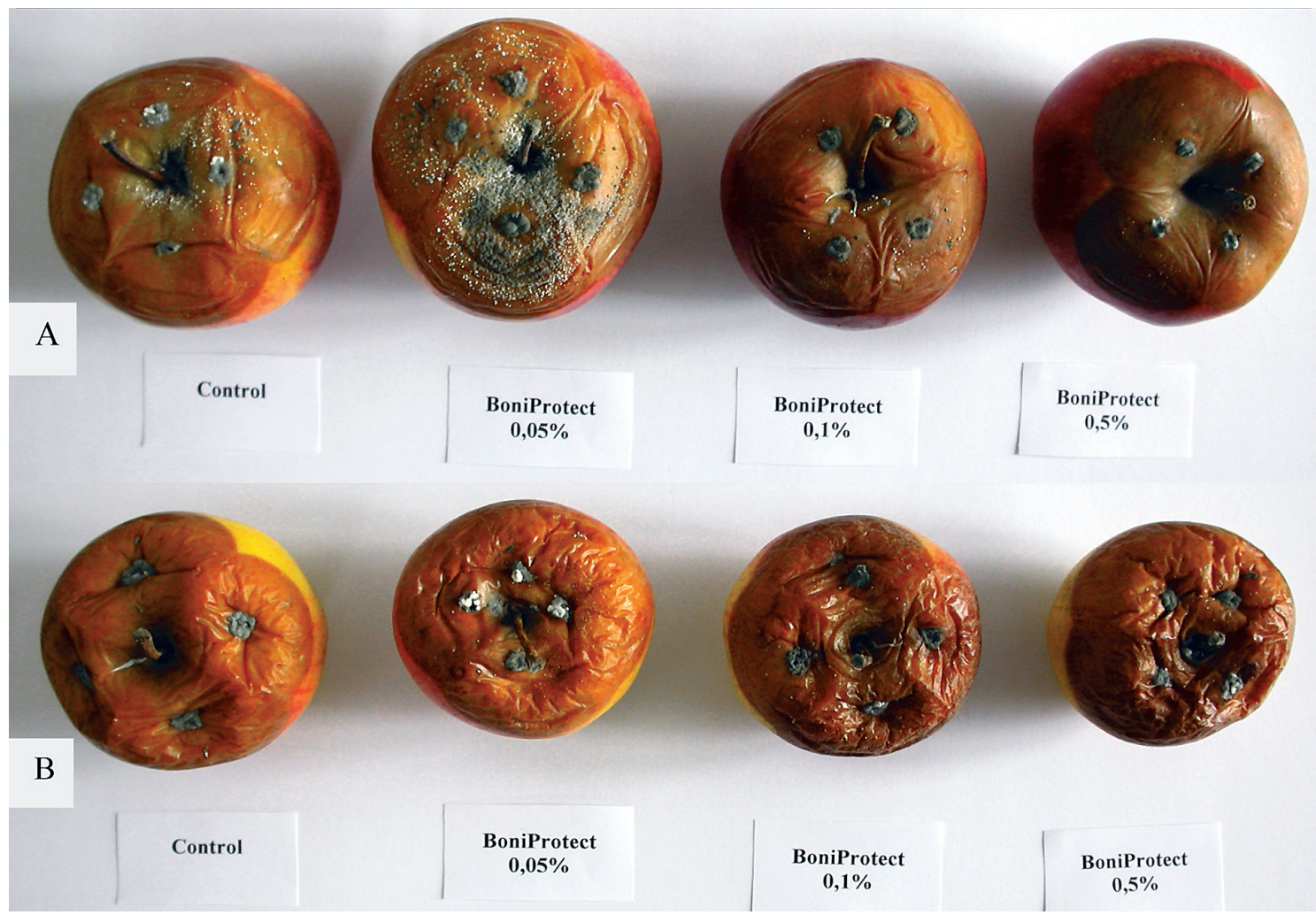

Fig. 11. Effect of Boni Protect on blue mold (Penicillim expansum) development on 'Jonagold Decosta' (A) and 'Pinova' (B) after 10 days.

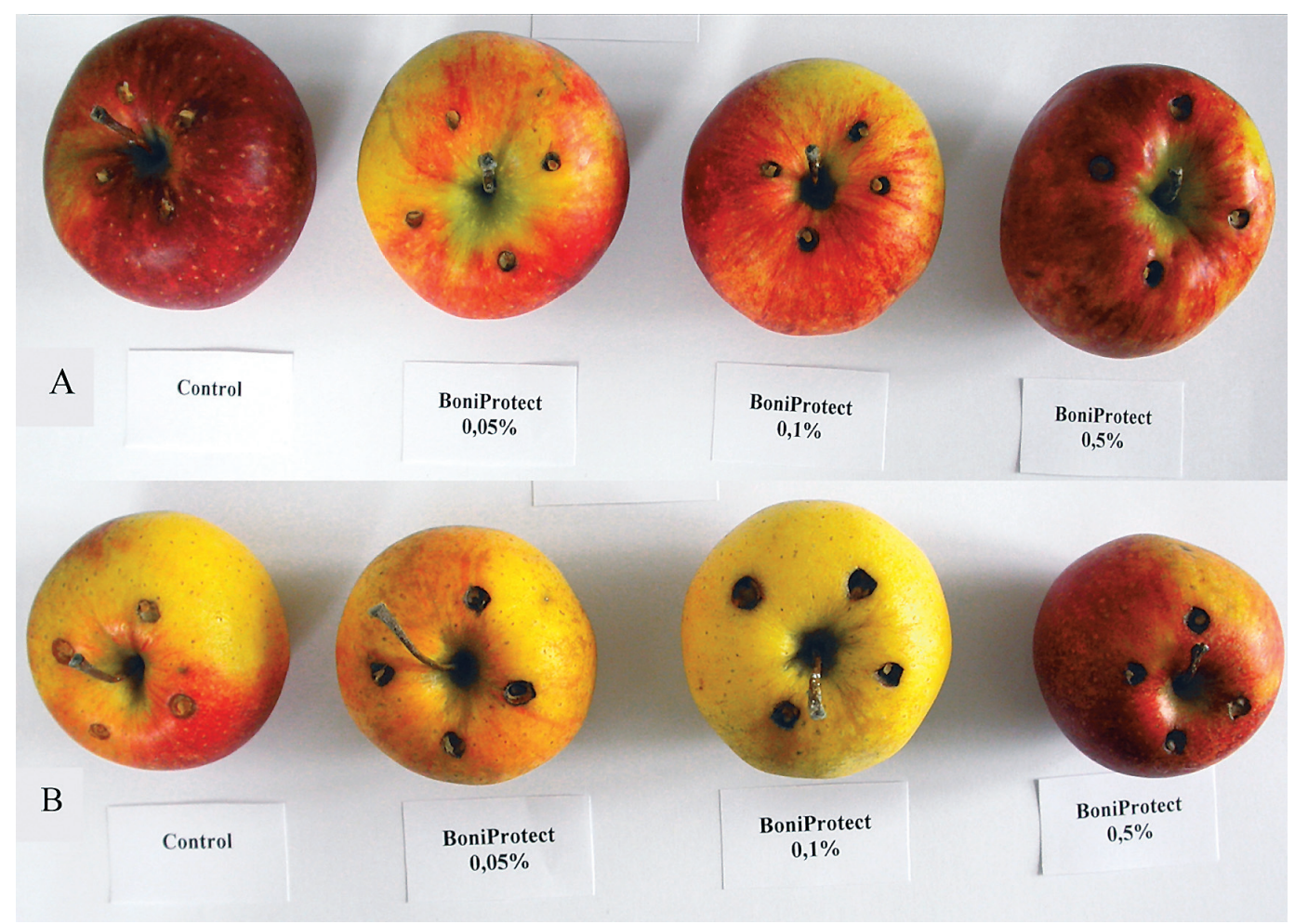

Fig.12. Effect of Boni Protect on bull's-eye rot (Pezicula malicorticis) development on 'Jonagold Decosta' (A) and 'Pinova' (B) after 10 days. 


\section{DISCUSSION}

Losses of fruits and vegetables during harvest, handling and storage are high. In Poland there are no registered fungicides for controlling postharvest diseases caused by $B$. cinerea, $M$. fructigena, and $P$. expansum. There are four products registered for $P$. malicorticis but some strains of this fungus are resistant to synthetic fungicides. In addition, consumers' concerns and restrictions about fungicide residues have made more ecological alternatives necessary.

The efficacy of biocontrol agents to control diseases of fruit and vegetables has been investigated by many researchers and several commercial products are now available in many countries (D r o b y et al. 1998; S u gar and S pott s, 1999; Li m a, 2003). Recently, yeasts and the yeast-like fungus A. pullulans are of special interest as antagonists. Similarly to yeasts, A. pullulans is an effective competitor for nutrients, especially for amino acids, iron and nitrogen (V e r o et al. 2002; B en cheqroun et al. 2006; Chi et al. 2009). It also produces antifungal compounds such as pullulan, protease, amylase, lipase, cellulase, xylanase and single cell protein ( $\mathrm{Ch}$ i et al. 2009). The fungus is also known for inducing plant defense mechanisms against fungi. It increases the activity of 1,3-glucanase, peroxidase and chitinase enzymes in wounds, which stimulates wound healing (Ippolito et al. 2000).

In the present research, A. pullulans in Boni Protect has proved quite effective to inhibit grey mold on apples. Similar results have been obtained by many researchers applying A. pullulans (Falconi and Mendgen 1994; Lima 1997). Achbani et al. (2005) observed complete control of B. cinerea on apples using selected strains of this fungus. The efficiency of A. pullulans in grey mold control seems to be similar to that of yeasts ( $\mathrm{S}$ a r a v a n a k u mar et al. 2008; S c harma et al. 2009). Although some authors have presented the ability of the fungus to protect fruits against brown rot $(\mathrm{Zhang}$ et al. 2010a, b), the biocontrol product was not always efficient in our study. Boni Protect inhibited the development of brown rot only in the concentration of $0.1 \%$ applied to 'Jonagold Decosta' apples. On 'Pinova' apples, the lesions in the treatments with the product were not significantly smaller than those in the control treatment.

Many reports show the abilities of A. pullulans to control $P$. expansum (E $1-\mathrm{Gh}$ a out et al. 2000; B encheqroun et al. 2006; $\mathrm{Zh}$ ang et al. 2010a). M o u n ir et al. (2007) observed the first symptoms of blue mold on apples only after 13 days since $A$. pullulans application. In our study the effect of Boni Protect on blue mold was rather poor even if in some combinations the lesions were significantly smaller than those in the control.
The most difficult to control with Boni Protect was $P$. malicorticis. Perhaps the concentration of the antagonist was too low, since Leibinger et al. (1997) proved that bull's-eye rot could be controlled only with high concentrations of A. pullulans.

The differences in Boni Protect efficacy between the cultivars, especially noticeable in the combinations with $B$. cinerea, are difficult to interpret. This cannot be explained by cultivar susceptibility. A u werkerke $n$ et al. (2007) proved that late-ripening cultivars are more resistant to $B$. cinerea than earlyripening ones. Both cultivars tested in our study are late-ripening, so this feature cannot have any effect on the results. Further studies are required to investigate the effect of cultivar on the efficiency of the biocontrol product in question.

\section{CONCLUSIONS}

1. Boni Protect (based on Aureobasidium pullulans) can be recommended for the protection of apples against Botrytis cinerea at all concentrations.

2. The biopreparation proved effective in the protection of apples against Monilinia fructigena only at a concentration of $0.1 \%$.

3. Boni Procect cannot be recommended for the protection of apples against Penicillium expansum and Pezicula malicorticis.

\section{Acknowledgements}

This research supported by the Ministry of Science and Higher Education of Poland as the part of statutory activities of Department of Plant Protection and Quarantine, University of Life Sciences in Lublin.

\section{REFERENCES}

Achbani E.H., Mounir R., El Jaafari S., Douira A., Benbouazza A., Jijakli M.H. 2005. Selection of antagonists against Penicillium expansum and Botrytis cinerea, two post harvest apple parasites. $57^{\text {th }}$ International Symposium on Crop Protection. Commun. Agric. Appl. Biol. Sci. 70 (3): 143-149.

Auwerkerken A., Davey M.W., Van Den Putte A., Keulemans J. 2007. Screening for Botrytis cinerea resistant apple cultivars. Acta Hort. 814: 759764.

Bencheqroun S.K., Bajji M., Massart S., Bentata F., Labhilili M., Achbani H., E1 Jaafari S., Jijakli M.H. 2006. Biocontrol of blue mold on apple fruits by Aureobasidium pullulans (strain Ach 1-1): in vitro and in situ evidence for possible involvement of competition for nutrients. Commun. Agric. Appl. Biol. Sci. 71 (3): 1151-1157.

B orecki Z. 1984. Fungicydy stosowane w ochronie roślin. PWN, Warszawa (in Polish). 
Chi Z., Wang F., Chi L., Yue L., Liu G., Zhang T. 2009. Bioproducts from Aureobasidium pullulans, biotechnologically important yeast. Appl. Micr. Biotech. 82: 793-804. http://dx.doi.org/10.1007/ s00253-009-1882-2

Droby S., Cohen L., Daus A., Weiss B., Horev B., Chalutz E., Katz H., Keren-Tzun M., Shachnai A. 1998. Commercial testing of Aspire: a yeast preparation for the biocontrol of postharvest decays citrus. Biol. Control, 12: 97-101.

E1-Ghaout A., Smilanick J., Wisniewski M., Wils on C.L. 2000. Improved control of apple and citrus fruit decay with a combination of Candida saitoa$n a$ and 2-deoxy-D-glucose. Plant Dis. 84: 249-253.

Falconi C.J., Mendgen K. 1994. Epiphytic fungi on apple leaves and their value for control of the postharvest pathogens Botrytis cinerea, Monilinia fructigena and Penicillium expansum. Z. Pflkrankh. Pflschutz. 101: 38-47.

Ippolito A., Ghaouth A. E., Wilson C. L., Wisn iewski M. 2000. Control of postharvest diseases of apple fruit by Aureobasidium pullulans and induction of defense responses. Postharv. Biol. Tec. 19: 265-272.

Leibinger W., Breuker B., Hahn M., Mendgen K. 1997. Control of postharvest pathogens and colonization of the apple surface by antagonistic microorganisms in the field. AGRIS Record, 87 (11): 1103-1110. http://dx.doi.org/10.1094/PHYTO.1997.87.11.1103

Lima G., Ippolito A., Nigro F., Salerno M. 1997. Effectiveness of Aureobasidium pullulans and Candida oleophila against postharvest strawberry rots. Postharv. Biol. Tec. 10: 169-178. http://dx.doi.org/ 10.1016/S0925-5214(96)01302-6

Lima G., De Curtis F., Castoria R., De Cicc o V. 2003. Integrated control of apple post- harvest pathogens and survival of biocontrol yeasts in semi-commercial conditions. Eur. J. Plant Pathol. 109: 341-349.

Mounir R., Durieux A., Bodo E., Allard C., Simon J.P., Achbani E.H., El-Jaafari S., Dounira A., Jijakli M.H. 2007. Production, formulation and antagonistic activity of the biocontrol like-yeast Aureobasidium pullulans against Penicillium expansum. Biotechnol. Lett. 29: 553-559. http://dx.doi. org/10.1007/s10529-006-9269-2

Pouliot J.M., Walton I., Parkhouse M.N., Abu-Lail L.I., and Camesano T.A. 2005. Adhesion of Aureobasidium pullulans is controlled by uronic acid based polymers and pullulan. Biomacromolecules, 6: 1122-1131.

Prasongsuk S., Sullivan R.F., Kuhirun M., Eveleigh D.E., and Punnapayak H. 2005. Thailand habitats as source of pullulan producing strains of Aureobasidium pullulans. World J. Microb. Biot. 21: 393-398. http://dx.doi.org/10.1007/s11274-004-2237-x

Rosslenbroich H.J., Stuebler D. 2000. Botrytis cinerea-history of chemical control and novel fungicides for its management. Crop Prot. 19: 557-561. http://dx.doi. org/10.1016/S0261-2194(00)00072-7

Saravanakumar D., Ciavorella K., Spadaro D., Garibaldi A., Gullino M.L. 2008. Metschnikowia pulcherrima strain MACH1 outcompetes Botrytis cinerea, Alternaria alternata and Penicillium expansum in apples through iron depletion. Postharv. Biol. Tec. 49: 121-128. http://dx.doi.org/10.1016/j.postharvbio.2007. 11.006

Scharma R.R., Singh D., Singh R. 2009. Biological control of postharvest diseases of fruits and vegetables. by microbial antagonists; A review. Biol. Control, 50(3): 205-222.

Schena L., Ippolito A., Zahavi T., Cohen L., Nigro F., and Droby S. 1999. Genetic diversity and biocontrol activity of Aureobasidium pullulans isolates against postharvest rots. Postharv. Biol. Tec. 17: 189199. http://dx.doi.org/10.1016/S0925-5214(99)00036-8

Schena L., Nigro F., Pentimone I., Ligorio A., and Ippolito A. 2003. Control of postharvest rots of sweet cherries and table grapes with endophytic isolates of Aureobasidium pullulans. Postharv. Biol. Tec. 30: 209220. http://dx.doi.org/10.1016/S0925-5214(03)00111-X

Sugar D., S potts R.A. 1999. Control of Postharvest Decay in Pear by Four Laboratory- grown Yeasts and Two Registered Biocontrol Products. Plant. Dis. 83 (2): 155158. http://dx.doi.org/10.1094/PDIS.1999.83.2.155

Takesako K., Ikai, K., Haruna F., Endo M., Shimanaka K., Sono E., Nakamura T., Kato I., and Yamaguchi H. 1991. Aureobasidins, new antifungal antibiotics. Taxonomy, fermentation, isolation and properties. J. Antibiot. 44: 919-924. http://dx.doi.org/10.7164/antibiotics.44.919

Vero S., Mondino P., Burgueno J., Soubes M., Wiśniewski M. 2002. Characterization of biocontrol activity of two yeast strains from Uruguay against blue mold of apple. Postharv. Biol. Tec. 26: 91-98. http://dx.doi.org/10.1016/S0925-5214(01)00199-5

Wagner A., Kordowska-Wiater M., Hetman B. 2006. Wpływ wybranych szczepów drożdży na rozwój szarej pleśni na owocach jabłoni. / Effect of selected yeast strains on grey mold development in apple fruits. Prog. Plant Prot. 46(2): 625-628 (in Polish).

Vinas I., Usall J., Teixido N., Sanchis V. 1998. Biological control of major postharvest pathogens on apple with Candida sake. Int. J. Food Microbiol. 40: 9-16.

Zhang A., Spadaro D., Garibaldi A., Gullino M.L. 2010a. Efficacy of antagonist Aureobasidium pullulans PL5 against postharvest pathogens of peach, apple and plum and its mode of action. Biol. Control, 54(3): 172180. http://dx.doi.org/10.1016/j.biocontrol.2010.05.003

Zhang A., Spadaro D., Garibaldi A., Gullino M.L. 2010b. Selection and evaluation of new antagonists for their efficacy against postharvest diseases of peaches. Postharv. Biol. Tec. 55: 174-181. 


\section{Laboratoryjna ocena \\ biopreparatu Boni Protect, zawierającego Aureobasidium pullulans (de Bary) Arnoud. (Boni Protect) do ochrony jabłek przed niektórymi chorobami grzybowymi}

\section{Streszczenie}

W warunkach laboratoryjnych badano skuteczność biopreparatu Boni Protect, zawierającego Aureobasidium pullulans (de Bary) Arnoud, w ochronie jabłek przeciwko Botrytis cinerea, Monilinia fructigena, Penicillium expansum i Pezicula malicorticis. Biopreparat stosowano $\mathrm{w}$ stężeniach $0,05 \%$, $0,1 \%$ i $0,5 \%$ na jabłkach odmian 'Jonagold Decosta' i 'Pinova'. Boni Protect był bardzo skuteczny w ochronie owoców 'Jonagold Decosta' przed B. cinerea, obniżając nasilenie choroby o $55-83.8 \%$. Na jabłkach odmiany ,Pinova' biopreparat był najbardziej skuteczny na początku doświadczenia. Hamował rozwój szarej pleśni o $65 \%$ po 5 dniach od inokulacji i tylko o $14 \%$ po 20 dniach. Boni Protect w stężeniu $0,1 \%$ był również skuteczny w ochronie jabłek 'Jonagold Decosta' przed M. fructigena, hamując rozwój brunatnej zgnilizny o 31,4-74,5\%, ale działanie na owoce odmiany 'Pinova' było znikome. Rozwój sinej pleśni, powodowanej przez $P$. expansum był hamowany tylko nieznacznie przez biopreparat, podczas gdy P. malicorticis okazał się najbardziej odporny na jego uzdolnienia antagonistyczne. 